\title{
RECOVERING GENETIC RESOURCES OF SOME LEGUME SPECIES OF LATVIAN ORIGIN BY PLANT TISSUE CULTURE
}

\author{
Dace Grauda*, Lita Lapiṇa*, ${ }^{\star *}$, Biruta Jansone ${ }^{\star \star *}$, Aldis Jansons ${ }^{\star \star *}$, and Isaak Rashal \\ * Institute of Biology, University of Latvia, Miera iela 3, Salaspils LV-2169, LATVIA; \\ dace@email.lubi.edu.lv; izaks@email.lubi.edu.Iv \\ ** Daugavpils University, Vienïbas iela 13, Daugavpils LV-5401, LATVIA \\ ${ }^{* * *}$ Research Institute of Agriculture, Latvia University of Agriculture, Skriveri LV-5125, LATVIA; \\ aldisjan@tvnet.lv
}

Contributed by Isaak Rashal

\begin{abstract}
Accessions with no germinating seeds are a common problem in plant gene banks and research institutions. Our goal was to elaborate and apply an in vitro method of germination and multiplication of old aged seeds of red and alsike clover and alfalfa. Eighteen clover and five alfalfa accessions were used for germination in vitro. Most of the accessions had produced seeds more than 20 years ago and the seeds did not germinate in soil. Seed pre-treatment with different concentrations of potassium permanganate, as well as addition of phytohormones, $\mathrm{AgNO}_{3}$ and activated carbon to germinating media were tested. Plantlets for all germinated accessions were obtained, even in the case when seeds were 44-year-old (alfalfa). Germination rate in vitro not always correlated with seed age and ranged from 2 to $72 \%$. Pre-treatment with potassium permanganate was effective both for seeds sterilisation and germination stimulation. Most germinated seeds formed phenotypically normal seedlings with all organs. In vitro multiplication of obtained clover plants was performed. Best results were achieved by micropropagation of stem segments approximately $2 \mathrm{~mm}$ in length. Number of finally obtained plants depended not only on seed germination ability, but also on micropropagation ability in relation to genotype, and on acclimatization success in soil after in vitro cultivation.
\end{abstract}

Key words: Trifolium pratense, Trifolium hybridum, Medicago sativa, aged seeds, in vitro germination.

\section{INTRODUCTION}

Red (Trifolium pratense), alsike (Trifolium hybridum) clovers and alfalfa (Medicago sativa) are the most popular fodder legumes suitable for growing in agronomical and ecological conditions of Latvia (Jansone, 1997). Clover breeding has been performed in Latvia since the 1920s and several widely used varieties were bred. Currently, only one alfalfa variety bred in Latvia ('Skrīveru') is registered for cultivation in Latvia (Jansone, 2008). For breeding of new varieties it is very important to have genetic resources with the necessary genetic variability. In the former Soviet Union, plant genetic resources activities were concentrated only in the N. Vavilov All-Union Institute of Plant Industry, now the N. Vavilov All-Russian Institute of Plant Industry, St. Petersburg, Russia (VIR). In 1993, when in Latvia plant genetic resources activities were started, it was recognised that many local varieties, as well as landraces and wild or semi-wild forms, were lost. Several accessions of Latvian origin were repatriated from the VIR and other gene banks. Seeds of the VIR collections were kept at room temperature. The majority of repatriated clover accessions were re- produced more than 20 years ago, some alfalfa accessions even 44 years ago, and therefore the seeds did not successfully germinate in soil.

Germination of seeds in in vitro culture conditions has been reported for many plants species, such as citrus Citrus sinensis (Niedz, 2008), strawberry (Hamdouni et al., 2001), almond (San and Yildirim, 2009) and others. Germination of old seeds is important for seed banking and conservation, for restoring genetic resources, to allow to improve modern plant breeding and cultivation, and to provide insight on the history of plant domestication and breeding. Special attention is paid on elaboration of methods for viability restoration of aged seeds, non-germinating in soil. In this respect, germination of an 1300-year-old seed is an unique case (Sallon et al., 2008).

There are known numerous factors that influence seed germination rate and seedlings growth: seed age and storage conditions (Rice and Dyer, 2001; Grauda et al., 2006; Valleriani and Tielbörger, 2006), age of mother plants (Raja et al., 2004; Espahbodi et al., 2007), heredity (Revilla et al., 
2009), conditions of seed germination and plantlet growth (Bhattacharya and Khuspe, 2001). Several tricks can improve aged seed germination ability: seed pre-treatment by temperature, light or phytohormones (Takayanagi and Harrington, 1971; Bhattacharya and Khuspe, 2001), and adding different phytohormones to cultivation medium (Bhattacharya and Khuspe, 2001; Soyler and Khawar, 2007). For various plant species, positive influence of $\mathrm{AgNO}_{3}$ on seed germination and plantlet formation in vitro has been shown (Ornicāne and Rashal, 1997); similar effects were found also for $\mathrm{KMnO}_{4}$ (Grauda et al., 2006), $\mathrm{KH}_{2} \mathrm{PO}_{4}$ (Sathish et al., 2011), activated carbon (Pacek-Bieniek et al., 2010) and $\mathrm{TiO}_{2}$ nanoparticles (Zheng et al., 2005). The goal of this study was to obtain mature plants from aged red and alsike clover and alfalfa seeds of accessions of Latvian origin by using in vitro methods.

\section{MATERIAL AND METHODS}

Seeds of alfalfa and clover accessions of Latvian origin that were repatriated from the N. Vavilov All-Russian Institute of Plant Industry (VIR) or were kept in the Latvian Research Institute of Agriculture (RIA) were used for the germination experiment (Table 1). The accessions had not been

Table 1

GERMINATION IN VITRO OF AGED SEEDS OF ALFALFA, ALSIKE AND RED CLOVER ACCESSIONS OF LATVIAN ORIGIN

\begin{tabular}{|c|c|c|c|c|}
\hline Accession name & Species & $\begin{array}{l}\text { Age of } \\
\text { seeds }\end{array}$ & $\begin{array}{c}\text { Seeds } \\
\text { source }\end{array}$ & $\begin{array}{l}\text { Germina- } \\
\text { tion rate } \\
\text { in vitro* }\end{array}$ \\
\hline Local k-31068 & Medicago sativa & 44 & VIR & 61.5 \\
\hline Local k-31069 & Medicago sativa & 44 & VIR & 62.0 \\
\hline Stendes vēlais 2 & Trifolium pratense & 34 & VIR & 12.5 \\
\hline Local k-33236 & Trifolium hybridum & 33 & VIR & 15.0 \\
\hline Local k-33240 & Trifolium hybridum & 33 & VIR & 9.5 \\
\hline Local k-33242 & Trifolium hybridum & 33 & VIR & 19.7 \\
\hline Local k-33246 & Trifolium hybridum & 33 & VIR & 14.7 \\
\hline Local k-25377 & Trifolium hybridum & 33 & VIR & 14.8 \\
\hline Skrīveru & Trifolium hybridum & 33 & VIR & 2.0 \\
\hline Local k-30428 & Trifolium pratense & 31 & VIR & 18.0 \\
\hline Local k-31023 & Trifolium pratense & 31 & VIR & 6.0 \\
\hline Local k-31106 & Trifolium hybridum & 31 & VIR & 15.0 \\
\hline Savvaḷas & Trifolium hybridum & 29 & VIR & 20.5 \\
\hline Vietējais & Trifolium hybridum & 29 & VIR & 14.0 \\
\hline Vietējais & Trifolium hybridum & 29 & VIR & 12.1 \\
\hline Vietējais agrais & Trifolium pratense & 29 & VIR & 17.0 \\
\hline Vietējais vēlais & Trifolium pratense & 29 & VIR & 2.9 \\
\hline Stendes agrais & Trifolium pratense & 27 & VIR & 6.5 \\
\hline $\begin{array}{l}\text { Priekulu } \\
\text { tetraploīdais }\end{array}$ & Trifolium hybridum & 24 & VIR & 16.0 \\
\hline Mentu kalna & Medicago sp. & 19 & RIA & 25.0 \\
\hline Priekuḷu 66 & Trifolium pratense & 16 & VIR & 71.8 \\
\hline Lucerna Nr. 2 & Medicago sp. & 15 & RIA & 2.0 \\
\hline Mežotnes & Medicago sp. & 14 & RIA & 18.0 \\
\hline
\end{tabular}

* - seeds of all accessions did not germinate in soil multiplied for a long time and all available seeds had lost germinating ability in the soil.

The in vitro germination experiment was conducted in two stages. In the first stage the best conditions of seed germination were determined for a sample of accessions; in the second stage, those were applied to the entire set of accessions.

Clover. For determination of the best concentration of $\mathrm{KMnO}_{4}$, in the first stage seeds of four clover accessions ('Vietējais agrais', 'Stendes vēlais 2', 'Priekuḷu tetraploidais', 'Vietējais') were soaked for 40 minutes both in $0.05 \%$ and $0.1 \%$ of $\mathrm{KMnO}_{4}$. For the remaining accessions, in the second stage of experiment only $0.1 \%$ concentration of $\mathrm{KMnO}_{4}$ was used. Seeds were sterilised in $50 \%$ solution of commercial bleach "Belizna" for 20 minutes, which had been found earlier to be optimal (Ornicāne and Rashal, 1997). The bleach solution was cooled to $10{ }^{\circ} \mathrm{C}$ before use, according to Yildiz and Er (2002).

To induce germination, 100-400 seeds from each accession were placed in Petri dishes on Murashige and Skoog (MS) basal medium (Murashige and Skoog, 1962) with $2 \mathrm{mg} / \mathrm{l} \mathrm{ki-}$ netin and $0.5 \mathrm{mg} / \mathrm{l} \mathrm{NAA}$, or on the MS basal medium without phytohormones (15-30 seeds in a Petri dish). Seeds were cultivated in darkness at $26{ }^{\circ} \mathrm{C}$. Germination rate was determined as number of germinated seeds to the total number of placed seeds.

Germinated seeds were placed on the MS basal medium without phytohormones and moved into light conditions at $24{ }^{\circ} \mathrm{C}$ (16 h day). Developed clover plantlets were multiplied by cuttings of different parts (stem segments, leaf petiole segments, leaf segments and axillary buds), placed on MS basal medium without phytohormones, and cultivated in light conditions at $24{ }^{\circ} \mathrm{C}$ (16 h day). Plantlets with good roots at stage of 3-4 leafs were planted in a plastic $(100 \mathrm{ml})$ pot and covered with plastic foil for better acclimatisation, and cultivated in a growing room ( $16 \mathrm{~h}$ day, $60 \%$ humidity, temperature $18-20{ }^{\circ} \mathrm{C}$ ). After several weeks of cultivation in the growing room, plants were moved to a greenhouse and grown for 2-3 months. Well developed plants were transferred for field trials and seed production to the Latvian Research Institute of Agriculture (RIA).

Alfalfa. Because only $1.0-1.5 \mathrm{~g}$ of seeds were available for accessions from the VIR, only alfalfa seeds of accessions from the Latvian Research Institute of Agriculture were used to determine the best pre-treatment and cultivation conditions. In the first stage, seed pre-treatment with both $0.07 \%$ and $0.1 \% \mathrm{KMnO}_{4}$ solution were performed for 40 or 60 minutes (Ornicāne and Rashal, 1997). Then seeds were sterilised by $50 \%$ solution of commercial bleach "Belizna" for 20 minutes. After pre-treatment, seeds were placed in Petri dishes on MS basal medium, or on the MS basal medium supplemented by $10 \mathrm{mg} / \mathrm{AgNO}_{3}$ or on the MS basal medium supplemented by $1 \mathrm{~g} / \mathrm{l}$ activated carbon. In the second stage, seeds of accessions from the VIR were germinated using pre-treatment by $0.1 \% \mathrm{KMnO}_{4}$ for 60 minutes and MS basal medium without supplements. 
All seeds were cultivated at $20-26{ }^{\circ} \mathrm{C}$ (16 h day) for $3-4$ weeks. Plantlets with good developed roots and 3-4 leafs were planted in soil in plastic pots $(100 \mathrm{ml})$ and cultivated in a greenhouse. For better acclimatisation, pots with plantlets were covered by plastic film. After acclimatisation, the plastic film was removed and plants were grown for 2-3 months. Good developed plants were planted in field conditions for seed production.

\section{RESULTS}

Seeds germination started after 10-14 days of cultivation in vitro and continued for the next 15 days. All viable seeds germinated within four weeks after initiation.

The seeds of different accessions showed various effects (Fig. 1) of the used $\mathrm{KMnO}_{4}$ concentrations for seeds soaking. For alsike clover, best results were for soaking in 0.1 $\% \mathrm{KMnO}_{4}$ solution, but on red clover the results obtained were similar for both used concentrations. Soaking in $0.1 \%$ $\mathrm{KMnO}_{4}$ solution decreased the percentage of infected seeds, depending on accession (data not shown).

For alfalfa, MS medium supplementation with $\mathrm{AgNO}_{3}$ or activated carbon did not significantly influence germination rate (Fig. 2). In addition, many plantlets obtained on the MS media supplemented with $\mathrm{AgNO}_{3}$ were soft, without roots and/or leaves and with tendency to calli formation (Fig. 3).

The highest germination rate for alfalfa was observed after pre-treatment with $0.1 \% \mathrm{KMnO}_{4}$ solution for 40 minutes (Fig. 4). Accession 'Lucerna Nr. 2' had the highest germination rate after pre-treatment with $0.07 \% \mathrm{KMnO}_{4}$ for

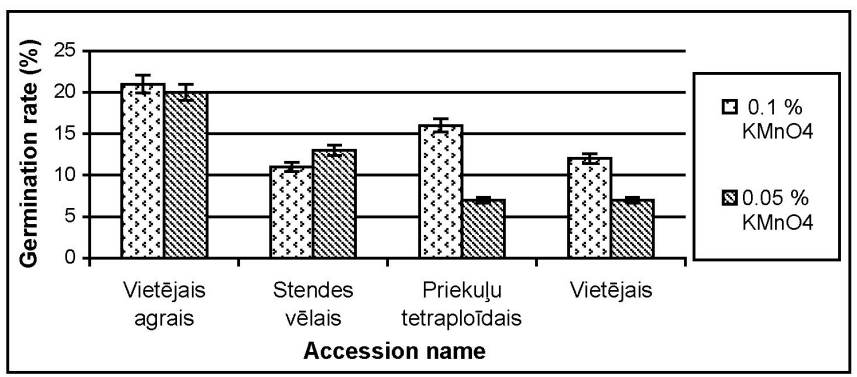

Fig. 1. Clover seed germination in relation to $\mathrm{KMnO}_{4}$ concentration.

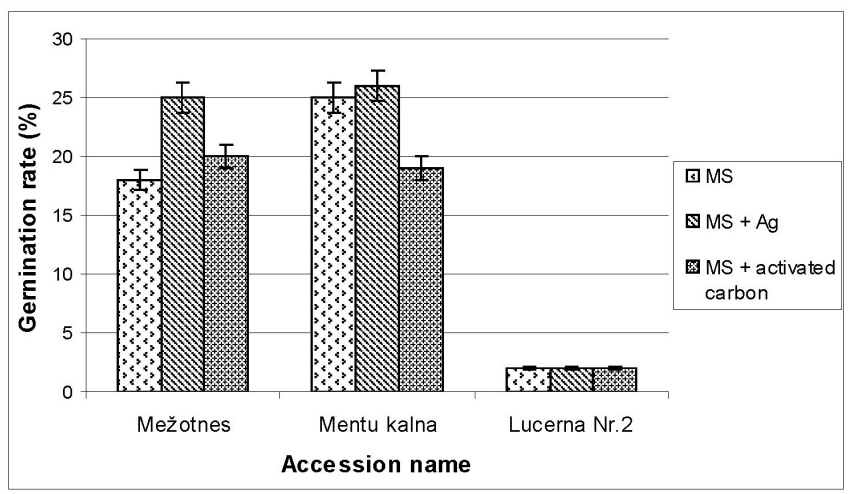

Fig. 2. Alfalfa seed germination after pre-treatment by $0.1 \% \mathrm{KMnO}_{4}$ depending on medium content.

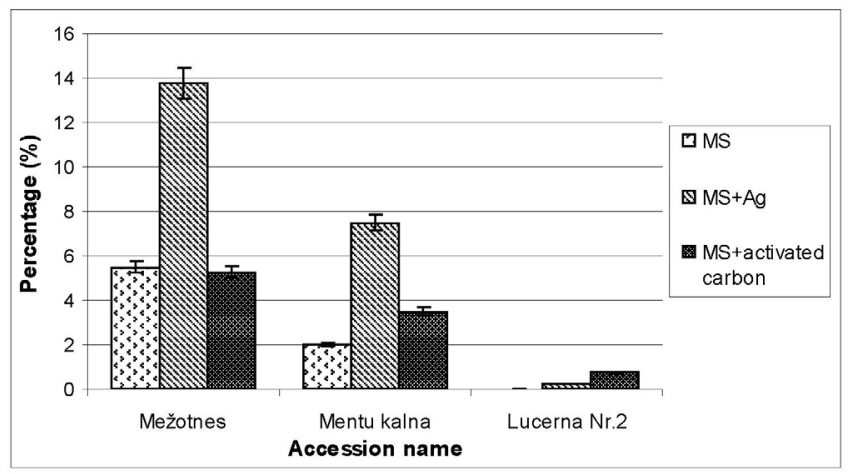

Fig. 3. Percentage of abnormal plantlets from germinated alfalfa seeds depending on medium content.

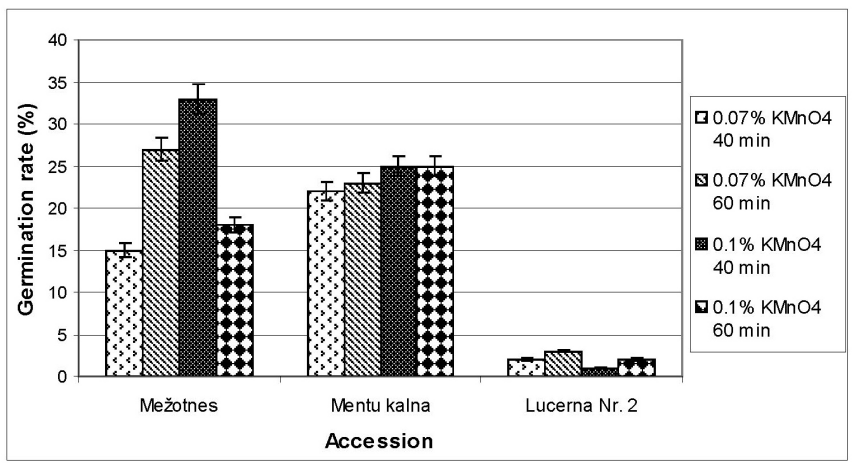

Fig. 4. Alfalfa seeds germination on MS basal medium depending on genotype.

60 minutes, but in this case some of the seeds were contaminated. Therefore, pre-treatment with the highest concentration of $\mathrm{KMnO}_{4}(0.1 \%)$ for 60 minutes and MS basal medium without supplement was chosen as the best conditions for in vitro germination of aged alfalfa seed.

The percentage of germinated seeds differed significantly depending on accessions, and was not always correlated with seeds age (Table 1). The germination rate reached $71.8 \%$ (clover) and $62 \%$ (alfalfa). Tolerance to long-term storage at room temperature varied both among and within species - red clover 'Vietējais vēlais' and alsike clover 'Savvalıas', 'Vietējais' (k-33239) and 'Vietējais' (k-33240) had the period of storage (29 years), but their germination rates differed by almost up to six times. The germination rate for both 44-year-old alfalfa seed accessions Local k-31068 and Local k-31069 was similar, but it is interesting that the germination rate for these accessions was significantly higher than for seeds with storage age 14-20 years.

Most germinated seeds formed phenotypically normal plantlets with all organs. An exception was the variety 'Stendes agrais': $23 \%$ plantlets did not form normal leaves, but only roots and stem. The use of phytohormones did not improve seed germination and had a negative influence on plantlets quality — after transfer into soil only $29 \%$ of plantlets started to grow, while $86 \%$ of plantlets grew after cultivation on medium without phytohormones.

After four weeks of in vitro cultivation, clover plantlets (stage of 3-4 leafs) were used for micropropagation. It was 
found that best results could be achieved by micropropagation of stem segments that were approximately $2 \mathrm{~mm}$ in length. Alsike accession 'Vietējais' developed axillary buds that were excellent explants for the second multiplication. From a plantlet, 2-7 new plantlets were obtained depending of genotype. After one month of cultivation, plantlets were ready for planting in soil or for the new cycle of multiplication. Positive results for micropropagation were not obtained only for accession 'Stendes agrais': stem segments started to grow but formed only non- regenerable calli.

\section{DISCUSSION}

The influence of different factors on in vitro germination rate of aged seed is known. One of the most important factors is seed sterilisation; the optimal method of sterilisation can considerably increase the seed ability for plant formation (de Sousa et al., 1999; Hamdouni, 2001; Yildiz and Er, 2002). It is also important to determine the optimal method of pre-treatment (Ornicāne and Rashal, 1997; Grauda and Rashal, 2004, Niedz, 2008; Sathish et al., 2011). Our results suggested that pre-treatment with potassium permanganate was effective for both seed sterilisation and germination stimulation; influence of genotype was observed in all used species. Cultivation medium and conditions are usually mentioned as main factors for seed in vitro germination and obtaining plantlets (Bhattacharya and Khuspe, 2001; Mauromicelle and Licandro, 2002; Klčová and Gubišová, 2003; Dutra et al., 2008; Greer et al., 2009; San and Yildirim, 2009; Mahamoodzadeh et al., 2010). Different effect of addition of silver ions or activated carbon to cultivation medium on the used genotypes was observed in our experiment.

Germination was successful for all accessions, even in the case of 44 years old seeds (alfalfa). It has been known for a long time) that seed germination differs between genotype (Rowley, 1956), as also observed for maize (Revilla et al., 2009) and in our study. Seed storage age can affect seed germination capacity; and plants regenerant formation is as source of mutations that can reduce seed germination and plant formation capacity (Rice and Dyer, 2001; Valleriani and Tielbörger, 2006; Esphbodi et al., 2007; Pereira et al., 2012). In our investigation seed germination rate not always correlated with seed age and ranged from $2-71 \%$. Most germinated seeds formed phenotypically normal seedlings with all organs. As an exception, only one genotype, 'Stendes agrais', produced plantlets that tended to form calli and were not useful for restoration of the due to possible somaclonal variation.

The best results were achieved by micropropagation of stem segments approximately $2 \mathrm{~mm}$ in length. The final number of obtained plants depended not only on seed germination ability, but also on micropropagation ability, in relation to genotype and acclimatisation success in soil after in vitro cultivation. The elaborated method can be used in plant genetic resource programmes for restoring poorly maintained accessions.

\section{ACKNOWLEDGEMENTS}

Part of this work was supported by the European Social Fund within the Project ,,Support for the implementation of doctoral studies at Daugavpils University" (Agreement Nr.2009/0140/1DP /1.1.2.1.2/09/IPIA/VIAA/ 015).

\section{REFERENCES}

Bhattacharya, J., Khuspe, S. S. (2001). In vitro and in vivo germination of papaya (Carica papaya L.) seeds. Sci. Hort., 91, 39-49.

Espahbodi, K., Hosseini, S. M., Mirzaie-Nodoushan, H., Tabari, M., Akbarinia, M., Dehghan-Shooraki, Y. (2007). Tree age effects on seed germination in Sorbus torminalis. Gen. Apl. Plant Physiol., 33 (1-2), 107-119.

De Sousa, P. B. L., De Santana, J. R. F., Crepaldi, I. C., Lima, A. R. (1999). Germination in vitro of seeds of a threatened arboreal specie in the municipal district of Abaira (BA). Sitientibus, 20, 89-99.

Dutra, D., Johnson, T. R., Kauth, P. J., Stewart, S. L., Kane, M. E., Richardson, L. (2008). Asymbiotic seed germination, in vitro seedling development, and greenhouse acclimatization of the threatened terrestrial orchid Bletia purpurea. Plant Cell Tiss. Organ. Cult., 94, 11-21.

Grauda, D., Rashal, I. (2004). Restoring clover genetic resources from the old seed material by plant tissue culture. In: Vlahos, I. (ed.). Competence Gene Transfer and Expression Special Aspects of Micropropagation (pp. 23-24). TEI of Crete: Herallion.

Grauda, D., Bērziṇa, I., Jansone, B., Rancāne, S., Rashal, I. (2006). Repatriation of red clover and alsike clover genetic resources of the Latvian origin. In: Jansone, B., Rašals, Ī., Svirskis, A., Benders, A. (eds.). 60 Years of Research at the Latvian Agricultural Institute (pp. 91-96). Skrīveri, Latvia: Research Institute of Agriculture.

Greer, S. P., Rinehart, T. (2009). In vitro germination and dormancy responses of Hydrangea macrophylla and Hydrangea paniculata seeds to ethyl methane sulfonate and cold treatment. HortScience, 44 (3), 764-769.

Hamdouni el, E. M., Lamarti, A., Badoc, A. (2001). In vitro germination of the achenes of strawberry (Fragaria $\times$ Ananassa Duch.) cvs 'Chandler' and 'Tudla'. Bull. Soc. Pharm. Bordeaux, 140, 31-42.

Jansone, B. (1997). Breeding achievements of forage grasses and legumes in Latvia. Plant Breeding: Theories, Achievements and Problems. DotnuvaAcademia, pp. 106-109.

Jansone, B. (2008). Guide Book in the Seed Production of Forage Grasses. Zemkopības zinātniskais institūts: Publishing Agency, 2008. 265 lpp.

Klčová, L., Gubišová, M. (2003). Utilisation of in vitro tehniques in rescue of gene resources of Meadow Vetchling (Lathyrus pratensis L.). Chech J. Genet. Plant Breed., 39 (3), 84-88.

Mahmoodzadeh, H., Abbasi, F., Rohani, S. (2010). In vitro germination and early seedling growth of Zinnia elegans. Res. J. Environ. Sci., 4 (4), 407-413.

Mauromicale, G., Licandro, P. (2002). Salinity and temperature effects on germination, emergence and seedling growth of globe artichoke. Agronomie, 22, 443-450.

Murashige, T., Skoog, F. (1962). A revised medium for rapid growth and bioassays with tobacco tissue culture. Plantarium, 15, 473-497.

Niedz, R. P. (2008). In vitro germination of citrus seed. Proc. Fla. State Hort. Soc., 21, 148-151.

Ornicāne, D., Rashal, I. (1997). Callus initiation from mature barley embryos and growth: Influence of silver nitrate and the method of sterilization. Proc. Latvian Acad. Sci. Section B, 51 (1/2), 72-74.

Pacek-Bieniek, A., Dyduch-Sieminska, M., Rudas, M. (2010). Influence of activated charcoal on seed germination and seedling development by the 
asymbiotic method in Zygostates grandiflora (Lindl.) Mansf. (Orchidaceae). Folia Horticulturae Ann., 22 (2), 45-50.

Pereira, M. J., Dias, E., Ramos, S. (2012). In vitro germination of four herbaceous species endemic to the Azores archipelago. Life Marine Sci., 29, 07-14.

Raja, K., Palanisamy, V., Selvaraju, P. (2004). Effect of palm age on seed germination and seedling vigour in arecanut (Areca catechu L.). Madaras Agric. J., 91 (4-6), 326-328.

Revilla, P., Butrón, A., Rodríguez, V. M., Malvar, R. A., Ordas, A. (2009). Identification of genes related to germination in aged maize seed by screening natural variability. J. Exper. Bot., 60 (14), 4151-4157.

Rice, K. J., Dyer, A. R. (2001). Seed aging, delayed germination and reduced competitive ability in Bromus tectorum. Plant Ecol., 155 (2), 237-243.

Rowley, G. D. (1956). Germination in Rosa canina. Amer. Rose Annu., 41, $70-73$.

Sallon, S., Solowey, E., Cohen, Y., Korchinsky, R., Egli, M., Woodhatch, I., Simchoni, O., Kislev, M. (2008). Germination, genetics and growth of an ancient date seed. Science, 320, 1464.
Sathish, S., Sundareswaran, S., Ganesan, N. (2011). Influence of seed priming on physiological performance of fresh and aged seeds of maize hybrid $[\mathrm{COH}(\mathrm{M}) 5]$ and it's parental lines. ARPN J. Agricult. Biol.l Sci., 6 (3), $12-17$

San, B., Yildirim, A. N. (2009). Seed and in vitro embryo germination in aged almond. Seed Sci. Technol., 37, 365-371.

Soyler, D., Khawar, K.M. (2007). Seed germination of caper (Capparis ovata var. herbacea) using $\alpha$ naphthalene acetic acid and gibberellic acid. Int. J. Agr. Biol., 9 (1), 35-37.

Takayanagi, K., Harrington, J. F. (1971). Enhancement of germination rate of aged seeds by ethylene. Plant Physiol., 47 (4), 521-524.

Yildiz, M. C., Er, C. (2002). The effect of sodium hypochlorite solutions on in vitro seedling growth and shoot regeneration of flax (Linum usitatissimum). Naturwissenschaften, 89, 259-261.

Valleriani, A., Tielbörger, K. (2006). Effect of age on germination of dormant seeds. Theor. Popul. Biol., 70, 1-9.

Zheng, L., Hong, F., Lu, S., Liu, C. (2005). Effect of nano-TiO 2 on strength of naturally aged seeds and growth of spinach. Biol. Trace Element Res., 104, 83-91.

Received 15 April 2013

\section{TAURIN̦ZIEŽU LATVIJAS IZCELSMES G̣ENĒTISKO RESURSU ATJAUNOŠANA AR AUDU KULTŪRAS PALĪDZĪBU}

Audu kultūras apstākḷos panākta tādu vecu āboliņa un lucernas sēklu izdīgšana, kuriem bija zaudēta dīgtspēja parastos apstākḷos. Iegūti fertīli augi, kuri papildina pieejamos ǵenētiskos resursus attiecīgo kultūraugu selekcijas vajadzībai. 